\title{
PERAMALAN JUMLAH WISATAWAN YANG BERKUNJUNG KE OBJEK WISATA DI JAWA TENGAH MENGGUNAKAN VARIASI KALENDER ISLAM REGARIMA
}

\author{
Haniela Puja Jesica1, Dwi Ispriyanti², Tarno $^{3}$ \\ 1,2,3 Departemen Statistika FSM Universitas Diponegoro \\ hanielapj@gmail.com
}

\begin{abstract}
Tourism is one of the most strategically controlled areas that have been developed.The number of tourists in Central Java is constantly rising in the month of Eid Al-Fitr caused by holiday and mudik to hometown. The shift of the Eid AlFitr month on the data will form a seasonal pattern with an unequal period, then called moving holiday effect.One of the calendar variationsare often used to remove the moving holiday effect is RegARIMA model. RegARIMA is a combination of the linier regression and ARIMA, which a weight was used as a regression variable and error of regression model was used a variable in the ARIMA process. Based on the analysis carried out on the monthly number of tourists visiting tourist attractions in Central Java data for the period January 2011 to December 2017, the RegARIMA $(1,1,1)(0,0,1)^{12}$ model as the best model because it have the lowest AIC value than other model. The forecasting results in 2018 shows an increase on number of tourists data on June 2018 which coincided with the Eid Al-Fitr holiday on 15 June 2018. sMAPE value is 23,298\%.
\end{abstract}

Keyowrds:Time Series, Tourists, RegARIMA, Moving Holiday Effect

\section{PENDAHULUAN}

Pariwisata merupakan salah satu sektor potensial yang strategis untuk terus dikembangkan. Pariwisata merupakan salah satu sumber utama pendapatan bagi banyak negara di dunia melalui penerimaan devisa negara (foreign exchange) dan penerimaan pajak (Sekretariat Jenderal DPR RI, 2019).

Menteri Pariwisata Arief Yahya mengungkapkan pada tahun 2017 bahwa jumlah wisatawan akan melonjak saat Lebaran Idul Fitri dikarenakan adanya tradisi mudik ke kampung halaman dan pastinya akan mendatangi objek wisata.Hari raya Idul Fitri ditetapkan berdasarkan kalender Islam, hal ini akan menyebabkan adanya pergeseran tanggal disetiap tahunnya pada kalender Masehi. Menurut Shuja' et al. (2007), tanggal perayaan hari raya Idul Fitri yang berpindah dari tahun ke tahun ini dikenal sebagai "moving holiday effect" yang merupakan salah satu jenis calendar effects.

Salah satu model variasi kalender yang sering digunakan untuk menghilangkan moving holiday effect adalah model RegARIMA dan dapat digunakan untuk forecasting. Model RegARIMA merupakan kobinasi antara model regresi dengan model ARIMA, dimana sebuah pembobot digunakan sebagai variabel regresi dan error dari model regresi digunakan sebagai variabel pada proses model ARIMA. 
Berdasarkan uraian tersebut maka studi kasus pada Tugas Akhir ini adalah peramalan jumlah wisatawan yang berkunjung ke objek wisata di Jawa Tengah dengan menerapkan model RegARIMA.

\section{TINJAUAN PUSTAKA}

\subsection{Pariwisata Jawa Tengah}

Berdasarkan catatan Disporapar Provinsi Jawa Tengah tahun 2017, jumlah wisatawan Mancanegara maupun wisatawan Nusantara setiap tahunnya mengalami peningkatan. Jumlah wisatawan Mancanegara pada tahun 2016 sebanyak 578.924 orang kemudian meningkat pada tahun 2017 menjadi 781.107 orang. Hal ini juga terjadi pada wisatawan Nusantara, dimana tahun 2016 terdapat 36.899.776 orang meningkat pada tahun 2017 menjadi 40.118 .470 orang.

\subsection{Matriks Pembobot}

Matriks pembobot digunakan sebagai variabel independen pada proses pemodelan regresi linier sederhana.Menurut Shuja'et al. (2007), terdapat tiga tipe variabel regresi yang digunakan yaitu:

a. REG1, digunakan untuk pembobotan satu variabel,

b. REG2, digunakan untuk pembobotan dua variabel,

c. REG3, digunakan untuk pembobotan tiga variabel.

Menurut Shuja' et al. (2007), variabel regresi REG1 dihitung menggunakan dua kriteria, yaitu:

Kriteria 1: jika tanggal perayaan jatuh pada awal bulan, yaitu tanggal 1-15, maka nilai bobot didefinisikan sebagai berikut:

$R E G 1= \begin{cases}\frac{n_{1}}{w}, & \text { untukbulan terjadi Idul Fitri } \\ \frac{n_{2}}{w}, & \text { untuk bulan sebelum terjadi Idul Fitri } \\ 0, & \text { untuk lainnya }\end{cases}$

dimana:

$\mathrm{n}_{1}$ : banyak hari yang berpengaruh pada bulan terjadi Idul Fitri

$\mathrm{n}_{2}$ : banyak hari yang berpengaruh pada bulan sebelum terjadi Idul Fitri

$\mathrm{w}$ : total hari yang berpengaruh.

Kriteria 2: jika tanggal perayaan jatuh pada akhir bulan, yaitu tanggal 16-31, maka nilai bobot didefinisikan sebagai berikut:

$R E G 1= \begin{cases}\frac{m_{1}}{w}, & \text { untukbulan terjadi Idul Fitri } \\ \frac{m_{2}}{w}, & \text { untuk bulan setelah terjadi Idul Fitri } \\ 0, & \text { untuk lainnya }\end{cases}$

dimana:

$\mathrm{m}_{1}$ : banyak hari yang berpengaruh pada bulan terjadi Idul Fitri

$\mathrm{m}_{2}$ : banyak hari yang berpengaruh pada bulan setelah terjadi Idul Fitri

$\mathrm{w}$ : total hari yang berpengaruh.

\subsection{Estimasi Parameter}

Estimasi parameter dilakukan menggunakan metode kuadrat terkecil maka nilai parameter $\beta$ dapat diestimasi dengan meminimumkan jumlah kuadrat residualnya. Jika $\hat{\beta}$ adalah estimasi dari $\beta$, maka diperoleh: 
jika:

$$
\widehat{\boldsymbol{Y}}_{\boldsymbol{t}}=\boldsymbol{X}_{\boldsymbol{t}} \hat{\beta}
$$

maka:

$$
Z_{t}=Y_{t}-\widehat{Y}_{t}
$$

$$
Z_{t}=Y_{t}-X_{t} \hat{\beta}
$$

dengan demikian fungsi kuadrat terkecil $L$ dari Persamaan (3) dapat dinyatakan sebagai berikut:

$$
L=\sum_{i=1}^{n} Z_{i}^{2}=\boldsymbol{Z}_{\boldsymbol{t}}^{\boldsymbol{T}} \boldsymbol{Z}_{\boldsymbol{t}}
$$

diperoleh fungsi kuadrat terkecil $\mathrm{L}$ sebagai berikut:

$$
L=\boldsymbol{Y}_{\boldsymbol{t}}^{T} \boldsymbol{Y}_{\boldsymbol{t}}-2 \hat{\beta} \boldsymbol{X}_{\boldsymbol{t}}^{T} \boldsymbol{Y}_{\boldsymbol{t}}+\hat{\beta} \boldsymbol{X}_{\boldsymbol{t}}^{T} \boldsymbol{X}_{\boldsymbol{t}} \hat{\boldsymbol{\beta}}
$$

dengan meminimumkan L terhadap $\hat{\beta}$, maka:

$$
\frac{\partial_{L}}{\partial_{\widehat{\beta}}}=-2 \boldsymbol{X}_{\boldsymbol{t}}{ }^{T} \boldsymbol{Y}_{\boldsymbol{t}}+2 \boldsymbol{X}_{\boldsymbol{t}}{ }^{T} \boldsymbol{X}_{\boldsymbol{t}} \hat{\beta}
$$

sehingga diperoleh estimasi parameter $\hat{\beta}$ sebagai berikut:

$$
\hat{\beta}=\left(\boldsymbol{X}_{\boldsymbol{t}}^{T} \boldsymbol{X}_{\boldsymbol{t}}\right)^{-1} \boldsymbol{X}_{\boldsymbol{t}}^{T} \boldsymbol{Y}_{\boldsymbol{t}}
$$

\subsection{Uji Signifikansi Parameter} individual.

Uji t digunakan untuk menguji signifikansi parameter regresi secara

Tahapan pengujian signifikansi parameter regresi adalah sebagai berikut:

a. Hipotesis:

$\mathrm{H}_{0}: \beta=0$ (parameter tidak berpengaruh signifikan terhadap respon yang diamati)

$\mathrm{H}_{1}: \beta \neq 0$ (parameter berpengaruh signifikan terhadap respon yang diamati).

b. Taraf signifikansi: $\alpha$

c. Statistik uji:

$$
t_{\text {hitung }}=\frac{\widehat{\beta}}{S E(\widehat{\beta})}
$$

dimana, $\hat{\beta}$ : estimasi parameter model; $S E(\hat{\beta})$ : standar error dari estimasi parameter model

d. Kriteria uji:

Tolak $\mathrm{H}_{0}$ jika nilai $\left|t_{\text {hitung }}\right|>t_{\left(\frac{\alpha}{2}, n-1\right)}$ atau $P_{\text {value }}<\alpha$, dimana n adalah ukuran sampel.

\subsection{Analisis Time Series}

\subsubsection{Model ARIMA}

\section{Autoregressive (AR)}

Menurut Wei (2006), secara umum model AR(p) dari suatu data time series $Z_{t}$ dengan $\mathrm{p}$ merupakan orde dari autoregressive dapat dituliskan sebagai berikut:

$$
Z_{t}=\phi_{1} z_{t-1}+\phi_{2} Z_{t-2}+\cdots+\phi_{p} Z_{t-p}+a_{t}
$$

\section{Moving Average (MA)}

Menurut Wei (2006), secara umum model MA(q) dari suatu data time series $Z_{t}$ dengan q merupakan orde dari moving average dapat dituliskan sebagai berikut:

$$
Z_{t}=a_{t}-\theta_{1} a_{t-1}-\theta_{2} a_{t-2}-\cdots-\theta_{q} a_{t-q}
$$




\section{Autoregressive Integrated Moving Average (ARIMA)}

Menurut Wei (2006), model ARIMA (p,d,q) adalah model gabungan dari $\mathrm{AR}(\mathrm{p})$ dan $\mathrm{MA}(\mathrm{q})$ dengan derajat pembedaan $d$ secara umum dituliskan sebagai berikut:

$\left(1-\phi_{1} B-\cdots-\phi_{p} B^{p}\right)(1-B)^{d} Z_{t}=\left(1-\theta_{1} B-\cdots-\theta_{q} B^{q}\right) a_{t}$

$\operatorname{dimana}(1-B)^{d}$ merupakan operator pembeda.

\section{Seasonal Autoregressive Integrated Moving Average (SARIMA)}

Menurut Wei (2006), model ARIMA dapat diperluas untuk menangani aspek musiman menjadi ARIMA $(\mathrm{p}, \mathrm{d}, \mathrm{q})(\mathrm{P}, \mathrm{D}, \mathrm{Q})^{\mathrm{S}}$ secara umum dituliskan sebagai berikut:

$$
\Phi_{P}\left(B^{S}\right) \phi_{p}(B)(1-B)^{d}\left(1-B^{S}\right)^{D} Z_{t}=\theta_{q}(B) \Theta_{Q}\left(B^{S}\right) a_{t}
$$

\subsubsection{Uji Signifikansi Parameter}

Uji signifikansi dapat dilakukan dengan tahap berikut:

a. Hipotesis:

$$
\begin{gathered}
\mathrm{H}_{0}: \Phi_{k}=0, k=1,2, \ldots, P \text { atau } \phi_{i}=0, i=1,2, \ldots, p \text { atau } \Theta_{l}=0, l= \\
1,2, \ldots, Q \text { atau } \theta_{j}=0, j=1,2, \ldots, q \\
\quad(\text { parameter tidak signifikan terhadap model ARIMA) } \\
\mathrm{H}_{1}: \Phi_{k} \neq 0, k=1,2, \ldots, P \text { atau } \phi_{i} \neq 0, i=1,2, \ldots, p \text { atau } \Theta_{l} \neq 0, l= \\
\quad 1,2, \ldots, Q \text { atau } \theta_{j} \neq 0, j=1,2, \ldots, q \\
\text { (parameter signifikan terhadap model ARIMA) }
\end{gathered}
$$

b. Taraf signifikansi: $\alpha$

c. Statistik uji:

$$
\begin{aligned}
& t_{\text {hitung }}=\frac{\widehat{\Phi}_{1}}{\operatorname{se}\left(\widehat{\Phi}_{1}\right)} \text { ataut } t_{\text {hitung }}=\frac{\widehat{\phi}_{1}}{\operatorname{se}\left(\widehat{\phi}_{1}\right)} \text { atau } \\
& t_{\text {hitung }}=\frac{\widehat{\theta}_{1}}{\operatorname{se}\left(\widehat{\theta}_{1}\right)} \text { atau } t_{\text {hitung }}=\frac{\widehat{\Theta}_{1}}{\operatorname{se}\left(\widehat{\Theta}_{1}\right)}
\end{aligned}
$$

d. Kriteria uji:

Tolak $\mathrm{H}_{0}$ jika nilai $\left|\mathrm{t}_{\text {hitung }}\right|>t_{\left(\frac{\alpha}{2}, n-s\right)}$ atau $P_{\text {value }}<\alpha$, dimana n adalah jumlah sampel dan $\mathrm{s}$ adalah jumlah parameter.

\subsubsection{Pemeriksaan Diagnostik}

\section{A. Uji White Noise Residual}

Menurut Wei (2006), uji Ljung-Box digunakan untuk mendeteksi apakah terdapat korelasi residual antar lag, dengan tahap pengujian sebagai berikut:

a. Hipotesis:

$\mathrm{H}_{0}: \rho_{1}=\rho_{2}=\cdots=\rho_{m}=0$ (tidak ada korelasi residual antar lag)

$\mathrm{H}_{1}$ : paling sedikit ada satu $\rho_{k} \neq 0$ dengan $\mathrm{k}=1,2, \ldots, \mathrm{m}$ (ada korelasi residual antar lag)

b. Taraf Signifikansi: $\alpha$

c. Statistik uji:

$$
Q_{\text {hitung }}=n(n+2) \sum_{k=1}^{m} \frac{\widehat{\rho}_{k}^{2}}{(n-k)}
$$

dengan, n: banyaknya pengamatan; m: banyaknya lag yang diuji; $\hat{\rho}_{k}$ : autokorelasi residual pada lag ke- $k$ 
d. Kriteria uji:

Tolak $\mathrm{H}_{0}$ jika $\mathrm{Q}_{\text {hitung }}>\chi_{(\alpha ; m-s)}^{2}$ atau $P_{\text {value }}<\alpha$, dengan s adalah banyaknya parameter.

B. Uji Normalitas Residual

Menurut Kabasarang et al. (2012), salah satu cara untuk menguji asumsi normalitas yaitu dengan menggunakan metode Jarque Bera (JB).

a. Hipotesis:

$\mathrm{H}_{0}$ : Residual berdistribusi normal

$\mathrm{H}_{1}$ : Residual tidak berdistribusi normal

b. Taraf Signifikansi: $\alpha$

c. Statistik uji:

$$
J B=\frac{n}{6}\left(S^{2}+\frac{(K-3)^{2}}{4}\right)
$$

dimana:

$$
S=\frac{\frac{1}{n} \sum_{t=1}^{n}\left(a_{t}-\bar{a}\right)^{3}}{\left(\frac{1}{n} \sum_{t=1}^{n}\left(a_{t}-\bar{a}^{2}\right)\right)^{3 / 2}} \operatorname{dan} K=\frac{\frac{1}{n} \sum_{t=1}^{n}\left(a_{t}-\bar{a}\right)^{4}}{\left(\frac{1}{n} \sum_{t=1}^{n}\left(a_{t}-\bar{a}\right)^{2}\right)^{2}}
$$

dengan, $\mathrm{n}$ : jumlah sampel; $\mathrm{S}$ : skewness; $\mathrm{K}$ : kurtosis

d. Kriteria uji:

Tolak $\mathrm{H}_{0}$ jika atau $\left.J B>\chi_{(\alpha ; 2)}^{2}\right)$. atau $P_{\text {value }}<\alpha$.

Menurut Rosadi (2012), asumsi normalitas residual dapat diabaikan, tidak sepenting uji white noise dari residual.

\subsection{Model RegARIMA}

Bell dan Hillmer (1983) mengemukakan bahwa data time series $\mathrm{Y}_{\mathrm{t}}$ yang mengandung efek variasi kalender dapat dituliskan dalam bentuk umum sebagai berikut:

$$
Y_{t}=f\left(X_{t}\right)+Z_{t}
$$

Bentuk persamaan regresi linier untuk data time series $\mathrm{Y}_{\mathrm{t}}$ sebagai berikut (Time Series Research Staff, 2011):

$$
Y_{t}=\beta X_{t}+Z_{t}
$$

Kombinasi persamaan SARIMA (Seasonal Autoregressive Integrated Moving Average) dan persamaan regresi linier, dengan mensubstitusikan persamaan (15) ke bentuk umum model SARIMA pada persamaan (10) maka diperoleh model umum RegARIMA sebagai berikut:

$$
\Phi_{P}\left(B^{S}\right) \phi_{p}(B)(1-B)^{d}\left(1-B^{S}\right)^{D}\left(Y_{t}-\beta X_{t}\right)=\theta_{q}(B) \Theta_{Q}\left(B^{S}\right) a_{t}
$$

Pemilihan model terbaik berdasarkan nilai AIC terkecil pada masing-masing model. Parameter model dikatakan baik jika parameter-parameternya signifikan dan mempunyai AIC terkecil.

\subsection{Pengujian Keakuratan Ramalan}

Makridakis dan Hibon (2000), mengemukakan bahwa salah satu ukuran yang digunakan untuk mengukur ketepatan peramalan adalah sMAPE (symmetric Mean Absolute Percentage Error). sMAPE menghitung ukuran presentase kesalahan dengan rumus sebagai berikut: 


$$
s M A P E=\frac{\sum_{i=1}^{n} \frac{\left|z_{i}-\bar{z}_{i}\right|}{\left(z_{i}+\widehat{z}_{i}\right) / 2}}{n} \times 100 \%
$$

dimana, n: banyaknya ramalan yang dilakukan; $\mathrm{Z}_{\mathrm{i}}$ : data actual; $\hat{Z}_{i}$ : data hasil ramalan.

Semakin kecil nilai sMAPE menunjukkan bahwa presentase kesalahan yang dihasilkan oleh model juga semakin kecil.

\section{METODE PENELITIAN}

\subsection{Jenis dan Sumber Data}

Jenis data yang digunakan dalam penelitian adalah data sekunder yang didapat dari Dinas Kepemudaan, Olahraga, dan Pariwisata Provinsi Jawa Tengah. Adapun data yang diambil adalah data jumlah wisatawan yang berkunjung ke objek wisata yang ada di Jawa Tengah periode Januari 2011 sampai dengan Desember 2018.

\subsection{Variabel Penelitian}

Data jumlah wisatawan dibagi menjadi dua, yaitu in sample dan out sample. Data in sample digunakan data periode Januari 2011 sampai dengan Desember 2017 untuk menentukan model, sedangkan data out sample digunakan data Januari sampai Desember 2018 untuk validasi peramalan atau pengukuran kesalahan model.

\subsection{Metode Analisis Data}

Pengolahan data pada penelitian ini menggunakan software R 3.5.2. Adapun langkah-langkah yang dilakukan untuk menganalisis data sebagai berikut:

1. Menginput data jumlah wisatawan $\left(\mathrm{Y}_{\mathrm{t}}\right)$ periode Januari 2011 sampai dengan Desember 2017 untuk peramalan dengan model RegARIMA.

2. Membuat plot time series dari data jumlah wisatawan $\left(\mathrm{Y}_{\mathrm{t}}\right)$, bertujuan untuk melihat pola yang terjadi pada data jumlah wisatawan $\left(\mathrm{Y}_{\mathrm{t}}\right)$.

3. Menentukan Regresor, yaitu menentukan variabel regresi yang memengaruhi jumlah wisatawan $\left(\mathbf{Y}_{\mathbf{t}}\right)$, dengan membentuk matriks pembobot $\mathbf{X}_{\mathbf{t}}$.

4. Membentuk model regresi linier antara $\mathbf{Y}_{\mathbf{t}}$ dengan $\mathbf{X}_{\mathbf{t}}$.

5. Melakukan perhitungan untuk nilai koefisien parameter regresi $\beta$, kemudian dilakukan uji signifikansi parameter, jika parameter $\beta$ tidak signifikan maka model tidak dipakai dan analisis tidak dapat dilanjutkan.

6. Menghitung residual (error) $\mathrm{Z}_{\mathrm{t}}$ dari model regresi linier.

7. Membuat plot time series $\mathrm{Z}_{\mathrm{t}}$.

8. Membentuk plot ACF dan plot PACF untuk identifikasi stasioneritas $Z_{t}$ baik stasioneritas dalam varian maupun stasioneritas dalam mean, jika belum stasioner maka dilakukan differencing untuk stasioneritas dalam mean dan transformasi Box-Cox untuk stasioneritas dalam varian.

9. Mengidentifikasi dugaan model RegARIMA menggunakan plot ACF dan PACF dari data $Z_{t}$.

10. Estimasi parameter dari model RegARIMA yang terbentuk, kemudian melakukan uji signifikansi parameter.

11. Melakukan diagnostik model, untuk mengetahui kesesuaian model yakni uji independensi residual dan uji normalitas residual.

12. Pemilihan model terbaik berdasarkan AIC. 
13. Membentuk persamaan model RegARIMA.

14. Melakukan peramalan.

15. Melakukan uji keakuratan model, untuk mengetahuinya digunakan nilai sMAPE.

16. Interpretasi hasil akhir yang diperoleh.

17. Selesai.

\section{HASIL DAN PEMBAHASAN}

\subsection{Plot Time Series $Y_{t}$}

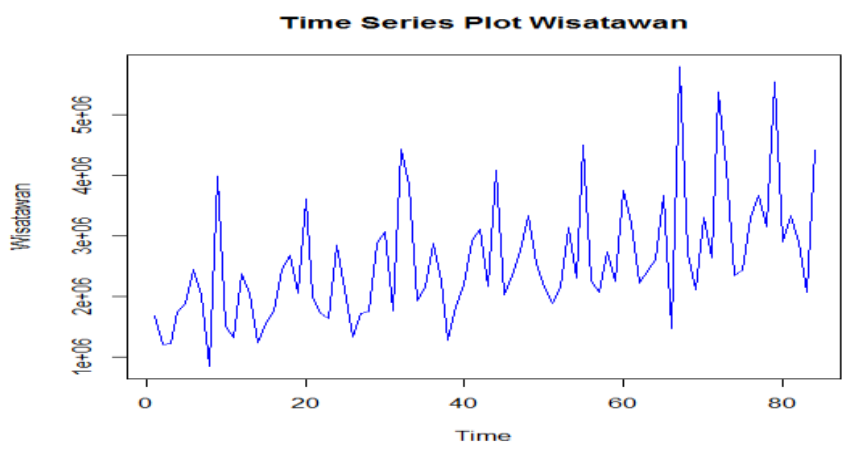

Gambar 1. Plot Time Series Data Wisatawan

Berdasarkan plot time series pada Gambar 1 dapat diidentifikasi bahwa data jumlah wisatawan memiliki pola trend dan pola musiman. Pola musiman dengan periode yang berbeda dideteksi karena terdapat beberapa titik yang mengalami peningkatan tajam yang diduga karena adanya hari raya Idul Fitri. Periode musiman yang berbeda ini mengindikasikan bahwa pada data jumlah wisatawan terdapat efek kalender yang disebabkan oleh adanya hari raya Idul Fitri.

\subsection{Matriks Pembobot}

Matriks pembobot ditentukan berdasarkan Persamaan (1) dan Persamaan (2). Perayaan Idul Fitri memengaruhi jumlah wisatawan selama 14 hari yaitu 7 hari sebelum Idul Fitri, saat Idul Fitri, dan 6 hari setelah Idul Fitri.

Tabel 3. Waktu Perayaan Idul Fitri tahun 2011-2017

\begin{tabular}{|c|c|c|c|c|c|c|}
\hline \multirow{2}{*}{ Waktu } & \multicolumn{3}{|c|}{$\begin{array}{c}\text { Banyak Hari yang } \\
\text { Berpengaruh }\end{array}$} & \multicolumn{3}{c|}{ Pembobot } \\
\cline { 2 - 8 } & $\begin{array}{c}\text { Sebelum } \\
\text { Bulan } \\
\text { Idul } \\
\text { Fitri }\end{array}$ & $\begin{array}{c}\text { Saat } \\
\text { Bulan } \\
\text { Idul } \\
\text { Fitri }\end{array}$ & $\begin{array}{c}\text { Sesudah } \\
\text { Bulan } \\
\text { Idul } \\
\text { Fitri }\end{array}$ & $\begin{array}{c}\text { Sebelum } \\
\text { Bulan } \\
\text { Idul Fitri }\end{array}$ & $\begin{array}{c}\text { Saat } \\
\text { Bulan } \\
\text { Idul Fitri }\end{array}$ & $\begin{array}{c}\text { Sesudah } \\
\text { Bulan } \\
\text { Idul Fitri }\end{array}$ \\
\hline 31 Agustus 2011 & 0 & 8 & 6 & 0 & 0.571429 & 0.428571 \\
\hline 19 Agustus 2012 & 0 & 14 & 0 & 0 & 1 & 0 \\
\hline 8 Agustus 2013 & 0 & 14 & 0 & 0 & 1 & 0 \\
\hline 28 Juli 2014 & 0 & 11 & 3 & 0 & 0.785714 & 0.214286 \\
\hline 17 Juli 2015 & 0 & 14 & 0 & 0 & 1 & 0 \\
\hline 6 Juli 2016 & 2 & 12 & 0 & 0.142857 & 0.857143 & 0 \\
\hline 25 Juni 2017 & 13 & 1 & 0 & 0.928571 & 0.071429 & 0 \\
\hline Bulan lainnya & 0 & 0 & 0 & 0 & 0 & 0 \\
\hline
\end{tabular}


Matriks pembobotnya sebagai berikut:

$$
\boldsymbol{X}_{\boldsymbol{t}}=\left[\begin{array}{c}
0 \\
0 \\
0 \\
0 \\
0 \\
0 \\
0 \\
0,57142857 \\
0,42857143 \\
\vdots \\
0,78571429 \\
0 \\
0 \\
0 \\
0 \\
\vdots \\
0,92857143 \\
0,07142857 \\
0 \\
0 \\
0 \\
0 \\
0
\end{array}\right]
$$

\subsection{Estimasi Parameter Model Regresi Linier}

Setelah diperoleh model regresi linier antara $\mathbf{Y}_{\mathbf{t}}$ dengan $\mathbf{X}_{\mathbf{t}}$, selanjutnya mengestimasi nilai parameter $\beta$ berdasarkan Persamaan (5) menggunakan software $R$ 3.5.2. diperoleh model regresi linier beserta estimasi parameter sebagai berikut:

$$
\widehat{Y_{t}}=X_{t} 4447851
$$

\subsection{Uji Signifikansi Parameter Model Regresi Linier}

Tabel 4. Nilai Signifikansi Parameter Model Regresi Linier

\begin{tabular}{|c|c|c|c|c|c|}
\hline$\hat{\beta}$ & $S E(\hat{\beta})$ & $\mathrm{P}_{\text {value }}$ & $\mathrm{t}_{\text {hitung }}$ & $\mathrm{T}_{0,025 ; 83}$ & Keputusan \\
\hline 4447851 & 1049729 & $5,83 \mathrm{e}-05$ & 4,237 & 1,98896 & Tolak $_{0}$ \\
\hline
\end{tabular}

Berdasarkan Tabel 4 bahwa estimasi parameter terhadap model regresi linier memiliki pengaruh yang signifikan, sehingga model dapat digunakan untuk analisis time series.

\subsection{Residual Regresi}


Selanjutnya menghitung residual regresi yang kemudian digunakan sebagai variabel pada analisis time series. Berdasarkan output software $R 3.5 .2$ dan Persamaan (4) dapat diperoleh residual $\left(Z_{t}\right)$ dari model regresi linier.

\subsection{Plot Time Series $\mathbf{Z}_{\mathbf{t}}$}

Plot time series dari data $Z_{t}$ yang dihasilkan menggunakan softwareR 3.5.2 dapat dilihat pada Gambar 2.

Time Series Plotzt

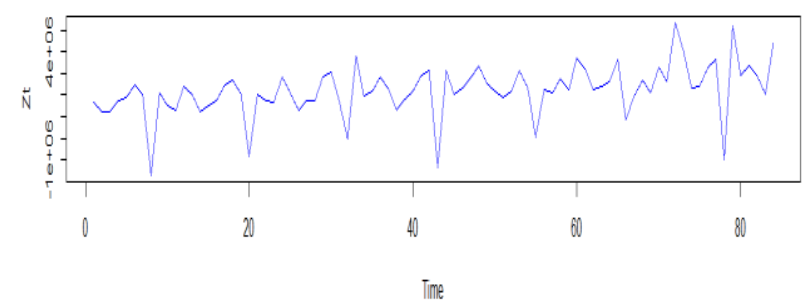

Gambar 2. Plot Time Series $Z_{t}$

Berdasarkan Gambar 2 dapat diidentifikasi bahwa data $Z_{t}$ memiiki pola trend sehingga disimpulkan bahwa data belum stasioner.

\subsection{Uji Stasioneritas}

\subsubsection{Uji Stasioneritas dalam Varian}

Kestasioneran dalam varian untuk $Z_{t}$ diuji menggunakan transformasi BoxCox. Menggunakan fungsi BoxCox.lambda dari software $R$ 3.5.2 diperoleh output estimasi lambda $(\lambda)$ sebesar 0,9999339 . Nilai tersebut mendekati satu sehingga dapat disimpulkan bahwa data $Z_{t}$ sudah stasioner dalam varian. Data $Z_{t}$ digunakan untuk tahapan selanjutnya.

\subsubsection{Uji Stasioneritas dalam Mean}

Berdasarkan sintaks dan output software $R$ 3.5.2, diperoleh nilai $P_{\text {valuesebesar }}$ 0,5981 artinya gagal tolak $\mathrm{H}_{0}$, sehingga dapat disimpulkan bahwa data $Z_{t}$ belum stasioner dalam mean. Selanjutnya dilakukan pembedaan (differencing) pada data $Z_{t}$. Berdasarkan sintaks dan output software $R$ 3.5.2, diperoleh nilai $P_{\text {valuesebesar }} 0,01528$ artinya $\mathrm{H}_{0}$ ditolak, sehingga dapat disimpulkan bahwa setelah dilakukan pembedaan derajat 1 pada data $Z_{t}$ sudah stasioner dalam mean.

\subsection{Identifikasi Model RegARIMA}

Model RegARIMA yang mungkin ditentukan berdasarkan plot ACF dan PACF adalah sebagai berikut:
1. RegARIMA $(1,1,1)(0,0,1)^{12}$
2. RegARIMA $(1,1,0)(0,0,1)^{12}$
10. RegARIMA $(1,1,1)$
3. RegARIMA $(2,1,1)(0,0,1)^{12}$
11. RegARIMA $(1,1,0)$
4. RegARIMA $(2,1,0)(0,0,1)^{12}$
12. RegARIMA $(2,1,1)$
5. RegARIMA $(3,1,1)(0,0,1)^{12}$
13. RegARIMA $(2,1,0)$
6. RegARIMA $(3,1,0)(0,0,1)^{12}$
14. RegARIMA $(3,1,1)$
7. RegARIMA $(11,1,1)(0,0,1)^{12}$
15. RegARIMA $(3,1,0)$
8. RegARIMA $(11,1,0)(0,0,1)^{12}$
16. RegARIMA $(11,1,1)$
9. RegARIMA $(0,1,1)(0,0,1)^{12}$
17. RegARIMA $(11,1,0)$
18. RegARIMA $(0,1,1)$ 


\subsection{Estimasi dan Uji Signifikansi Parameter Model RegARIMA}

Pada taraf signifikansi 5\% yang signifikansi adalah RegARIMA $(1,1,1)$ $(0,0,1)^{12}$, RegARIMA $(1,1,0)(0,0,1)^{12}$, RegARIMA $(2,1,0)(0,0,1)^{12}$, RegARIMA $(3,1,0)(0,0,1)^{12}$, RegARIMA $(0,1,1)(0,0,1)^{12}$, RegARIMA $(1,1,0)$, RegARIMA $(2,1,0)$, RegARIMA $(3,1,0)$, RegARIMA $(11,1,0)$, dan RegARIMA $(0,1,1)$. Model-model tersebut akan dianalisis lebih lanjut dengan menguji white noise residual dari masing-masing modelnya.

\subsection{Uji White Noise Residual Model RegARIMA}

Tabel 6. Uji White Noise Residual Model RegARIMA

\begin{tabular}{|l|c|c|}
\hline Model & Analisis & Keputusan \\
\hline RegARIMA $(1,1,1)(0,0,1)^{12}$ & Semua $P_{\text {value }}>\alpha$ & Gagal tolak $\mathrm{H}_{0}$ \\
\hline RegARIMA $(1,1,0)(0,0,1)^{12}$ & Ada beberapa $P_{\text {value }}<\alpha$ & Tolak $\mathrm{H}_{0}$ \\
\hline RegARIMA $(2,1,0)(0,0,1)^{12}$ & Ada beberapa $P_{\text {value }}<\alpha$ & Tolak $\mathrm{H}_{0}$ \\
\hline RegARIMA $(3,1,0)(0,0,1)^{12}$ & Ada beberapa $P_{\text {value }}<\alpha$ & Tolak $\mathrm{H}_{0}$ \\
\hline RegARIMA $(0,1,1)(0,0,1)^{12}$ & Ada beberapa $P_{\text {value }}<\alpha$ & Tolak $\mathrm{H}_{0}$ \\
\hline RegARIMA $(1,1,0)$ & Semua $P_{\text {value }}<\alpha$ & Tolak $\mathrm{H}_{0}$ \\
\hline RegARIMA $(2,1,0)$ & Semua $P_{\text {value }}<\alpha$ & Tolak $\mathrm{H}_{0}$ \\
\hline RegARIMA $(3,1,0)$ & Semua $P_{\text {value }}<\alpha$ & Tolak $\mathrm{H}_{0}$ \\
\hline RegARIMA $(11,1,0)$ & Semua $P_{\text {value }}>\alpha$ & Gagal tolak $\mathrm{H}_{0}$ \\
\hline RegARIMA $(0,1,1)$ & Ada beberapa $P_{\text {value }}<\alpha$ & Tolak $\mathrm{H}_{0}$ \\
\hline
\end{tabular}

Berdasarkan Tabel 6, dapat disimpulkan bahwa model RegARIMA $(1,1,1)$ $(0,0,1)^{12}$ dan RegARIMA $(11,1,0)$ residualnya memenuhi asumsi white noise.

\subsection{Uji Normalitas Residual Model RegARIMA}

Tabel 7. Uji Normalitas Residual Model RegARIMA

\begin{tabular}{|l|c|c|c|}
\hline \multicolumn{1}{|c|}{ Model } & Jarque Bera & $P_{\text {value }}$ & Keputusan \\
\hline RegARIMA $(1,1,1)(0,0,1)^{12}$ & 71,436 & $3,331 \mathrm{e}-16$ & Tolak $\mathrm{H}_{0}$ \\
\hline RegARIMA $(11,1,0)$ & 41,812 & $8,329 \mathrm{e}-10$ & Tolak $\mathrm{H}_{0}$ \\
\hline
\end{tabular}

Berdasarkan Tabel 7, dapat disimpulkan bahwa tidak ada model RegARIMA yang memenuhi asumsi normalitas. Asumsi normalitas residual tidak sepenting uji white noise dari residual, sehingga dapat diabaikan dan dilanjutkan dengan pemilihan model terbaik (Rosadi, 2012).

\subsection{Pemilihan Model RegARIMA Terbaik}

Tabel 8. Nilai AIC Model RegARIMA

\begin{tabular}{|l|c|}
\hline \multicolumn{1}{|c|}{ Model } & Nilai AIC \\
\hline RegARIMA $(1,1,1)(0,0,1)^{12}$ & 1524,65 \\
\hline RegARIMA $(11,1,0)$ & 2514,52 \\
\hline
\end{tabular}

Berdasarkan Tabel 8, dapat disimpulkan bahwa RegARIMA $(1,1,1)(0,0,1)^{12}$ merupakan model terbaik karena memiliki nilai AIC terkecil dibandingkan dengan model RegARIMA yang lainnya.

Model RegARIMA $(1,1,1)(0,0,1)^{12}$ adalah sebagai berikut:

$$
\begin{gathered}
Y_{t}=4447851 X_{t}+0,7047 Z_{t-1}+0,2953 Z_{t-2}+a_{t}+0,9119 a_{t-1}- \\
0,5963 a_{t-12}-0,5438 a_{t-13}
\end{gathered}
$$

\subsection{Peramalan}


Model akhir yang digunakan untuk peramalan yaitu, model RegARIMA $(1,1,1)(0,0,1)^{12}$ pada Persamaan (18) maka dihasikan forecasting selama 12 periode sebagai berikut:

Tabel 9. Peramalan $Z_{t}$

\begin{tabular}{|c|c|c|c|}
\hline $\mathrm{t}$ & $\mathrm{i}$ & Waktu & $F_{i}$ \\
\hline 85 & 1 & Januari 2018 & 3416554 \\
\hline 86 & 2 & Februari 2018 & 2808461 \\
\hline 87 & 3 & Maret 2018 & 2652622 \\
\hline 88 & 4 & April 2018 & 3123396 \\
\hline 89 & 5 & Mei 2018 & 3142264 \\
\hline 90 & 6 & Juni 2018 & 5636489 \\
\hline 91 & 7 & Juli 2018 & 4482728 \\
\hline 92 & 8 & Agustus 2018 & 2676048 \\
\hline 93 & 9 & September 2018 & 3464939 \\
\hline 94 & 10 & Oktober 2018 & 2747927 \\
\hline 95 & 11 & November 2018 & 2355720 \\
\hline 96 & 12 & Desember 2018 & 3052626 \\
\hline
\end{tabular}

\subsection{Nilai sMAPE}

Berdasarkan Persamaan (17), diperoleh nilai sMAPE sebesar 0,23298 atau $23,298 \%$.

\subsection{Interpretasi}

Berdasarkan hasil peramalan pada Tabel 9, peningkatan jumlah wisatawan yang berkunjung ke objek wisata yang di Jawa Tengah terbesar terjadi pada Juni 2018 yaitu 5.636.489 orang. Hal ini bertepatan dengan adanya hari raya Idul Fitri yang jatuh pada tanggal 15 Juni 2018. Kesimpulannya adalah peramalan dengan variasi kalender Islam menggunakan RegARIMA berhasil menangani efek moving hoiday yang terdapat pada data jumlah wisatawan yang berkunjung ke objek wisata yang ada di Jawa Tengah tahun 2011-2017.

\section{KESIMPULAN}

Berdasarkan hasil dan pembahasan yang teah dilakukan maka dapat diambil kesimpulan sebagai berikut:

1. Data jumlah wisatawan yang berkunjung ke objek wisata yang ada di Jawa Tengah pada tahun 2011-2017 diidentifikasi terdapat pola trend dan pola musiman dengan periode yang berbeda disetiap tahunnya.

2. Model RegARIMA mampu menghilangkan efek kalender pada data jumlah wisatawan yang berkunjung ke objek wisata yang ada di Jawa Tengah, dimana data tersebut mengandung efek moving holiday dengan model terbaik yaitu RegARIMA $(1,1,1)(0,0,1)^{12}$.

3. Peramalan jumlah wisatawan yang berkunjung ke objek wisata yang ada di Jawa Tengah untuk periode Januari 2018 sampai Desember 2018 dilakukan menggunakan model RegARIMA terbaik. Hasil peramalan menunjukkan peningkatan jumlah wisatawan yang berkunjung ke objek wisata yang di Jawa Tengah terbesar terjadi pada Juni 2018 yaitu 5.636.489 orang. Hal ini bertepatan dengan adanya hari raya Idul Fitri yang jatuh pada tanggal 15 Juni 2018. Nilai sMAPE yang diperoleh adalah sebesar 0,23298 atau $23,298 \%$. 


\section{DAFTAR PUSTAKA}

Aswi \& Sukarna. 2006. Analisis Deret Waktu Teori dan Aplikasi.Makassar: Andira Publisher.

Bell, W. R. \& Hillmer, S. C. 1983. Modeling Time Series with Calendar Variation. Journal of Business and Economic Statistic: Hal. 526-534.

Dinas Kepemudaan, Olahraga, dan Pariwisata (Disporapar). 2017. Statistik Pariwisata Jawa Tengah 2017.Semarang: Dinas Kepemudaan, Olahraga, dan Pariwisata Provinsi Jawa Tengah.

Kabasarang, D. C., Setiawan, A. \& Susanto, B. 2012. Uji Normalitas Menggunakan Statistik Jarque-Bera Berdasarkan Metode Bootstrap.Salatiga.

Makridakis, S., \& Hibon, M. 2000. The M3-Competition: Result, Conclusions and Implications.International Journal of Forecasting, Vol. 16, Hal: 451-476.

Makridakis, S., Wheelwright, S. C. \& McGee, V. E. 1995. Metode dan Aplikasi Peramalan Edisi Kedua Jilid I.Jakarta: Erlangga.

Rosadi, D. 2012. Ekonometrika dan Analisis Runtun Waktu Terapan dengan Eviews. Yogyakarta: ANDI.

Sarhani, M. \& Afia, A. E. 2014. An Extension of X-13-ARIMA-SEATS to Forecast Islamic Holiday Effect on Logistic Activities.Journal of IEEE.

Sekretariat Jenderal DPR RI.31 Mei 2019. Pariwisata Berikan Kontribusi pada Pendapatan Negara. Dewan Perwakilan Rakyat Republik Indonesia.

Shuja', N., Lazim, M. A. \& Wah, Y. B. 2007. Moving Holiday Effects Adjustment for Malaysian Economic Time Series.Department of Statistics Malaysia, Vol. 1, Hal: 35-50.

Time Series Research Staff Division Room 3000-4 U.S Census Bureau. 2011. X12-ARIMA Reference Manual Version 0.3.Washington DC: U.S Census Bureau.

Wei, W. W. S. 2006. Time Series Analysis: Univariate and Multivariate Method.New York: Person Education Inc. 